\title{
The Intensive Exchanges Flows: About a "New Regionalism»: OBOR («One Belt, One Road»)
}

\author{
Stéphane Callens ${ }^{*}$, Sofiane Cherfi \\ LEM (Lille Economy and Management), UMR 9221 CNRS (National Center for Scientific Research), University of Artois, France
}

Copyright $(2017$ by authors, all rights reserved. Authors agree that this article remains permanently open access under the terms of the Creative Commons Attribution License 4.0 International License

\begin{abstract}
Regional trade agreements (RTAs) are susceptible to create a traffic diversion. Since the beginning of the millennium, multilateralism stalled (cycle Doha down) where so-called regional's policies are impulse whether from United States (TPP, TTIP) or China (OBOR: New Silk Road launched in 2013). These attempts agreements take place in the areas traversed by intensive exchanges flows, tangible and intangible. Knowledge, Innovation and Trade reinforce each other by intensity. The «intensive exchanges flows» are the transformation of macroeconomics solidarities. Since 1986, a global business cycle is based on a more or less highly dynamic of exchanges rather an informal regionalism of major trade roads. Exchange and Knowledge are joined, but with non-linearity: spillovers of knowledge are bigger if exchanges are more than average.
\end{abstract}

Keywords Innovation, China, OBOR, Regional Trade Agreements

JEL CLASSIFICATION: O24

\section{Introduction: Analysis of a "New Regionalism"}

The difficulties faced by the Doha Round multilateral negotiations led to regional initiatives. This "new regionalism" has partnership around common characteristics of intense trade flows, tangible and intangible. This new regionalism is that of intense trade flows.

This regionalism of the period of globalization is the fourth historic phase of regional economic integration: 1 / in the nineteenth century had a first phase of regional trade agreements that contributed to unification of countries as the Germany or Italy. 2 / then protectionism and the diversion of traffic created colonial blocs. 3 / The Association of Southeast Asia (ASEAN) were established in 1967 to reduce tensions between authoritarian regimes and the outbreak of armed conflicts. 4 / finally, in the period of globalization, after 1986, economic motivations dominated and led a multiplication of RTAs.

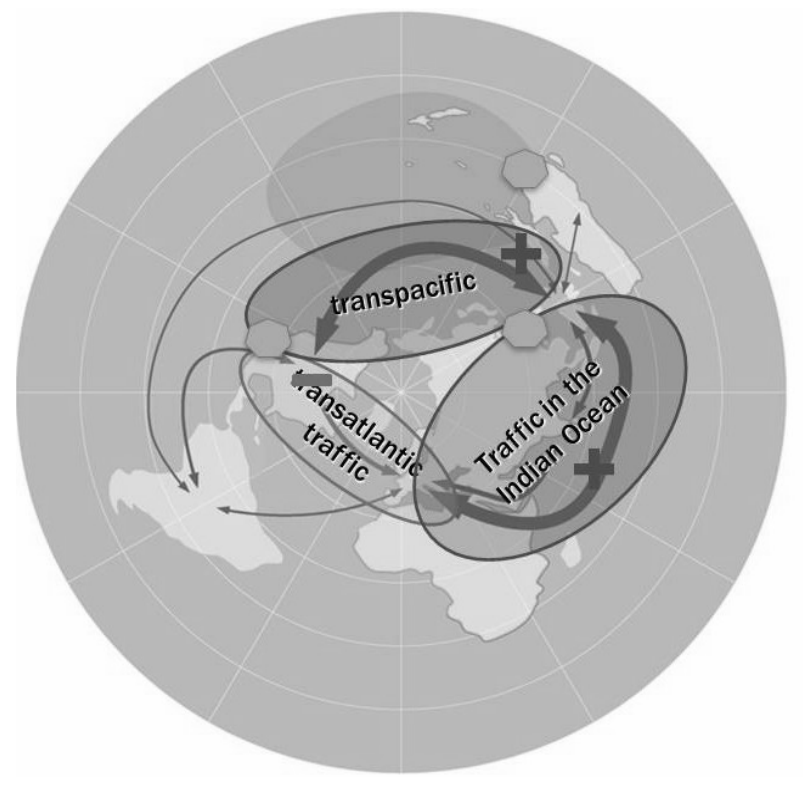

Figure 1. World traffic of containers

\begin{tabular}{|c|c|}
\hline Regionalism type & Main caracteristic \\
\hline $\begin{array}{c}\text { Regionalism of National } \\
\text { romantism }\end{array}$ & $\begin{array}{c}\text { Protectionism of the emerging } \\
\text { industry; New nation with Customs } \\
\text { Union }\end{array}$ \\
\hline Block Policy & $\begin{array}{c}\text { Great diversion of traffic, block or } \\
\text { colonial governance }\end{array}$ \\
\hline Regionalism of pacification & $\begin{array}{c}\text { Prevention of armed conflicts } \\
\text { (example: ASEAN, 1967) }\end{array}$ \\
\hline $\begin{array}{c}\text { Regionalism of globalization } \\
\text { ("Spaghetti" or "Fried Egg") }\end{array}$ & $\begin{array}{c}\text { Management of effects of increased } \\
\text { trade }\end{array}$ \\
\hline
\end{tabular}

Figure 2. Four regionalisms

Asia is the second region number of regional agreements force in the World, after Europe. We limit ourselves here, the most recent expression of regionalism, through the Chinese initiative of the New Silk Road, again referred to by the acronym "One Belt, One Road: OBOR" or the simplified expression "Belt \& Road". This new regionalism introduced by Chinese politics expressed for the first time in official travels of President Xi Jinping in Indonesia and Kazakhstan in October 2013. This is a turning point in the Chinese attitude, which focuses on the outside an unusual way 
compared to traditional Chinese politics.

The lack dynamism in the multilateral agreements since 2001 has led the blossoming of "regionalism - spaghetti". Today, less than 285 RTAs are forced in the world, according to the WTO database. A large amount of them were signed in the period 2001-2008. Among the agreements
RTA in force today, $16 \%$ are forced date before 2001 , and $30 \%$ after 2009 . The metaphor of "spaghetti regionalism" is that the countries of the world with 15 agreements RTA on average. China participates with RTA agreements in 2002 to attitude of "spaghetti regionalism". Today, China's RTA agreements are forced mainly concern South-East Asia.

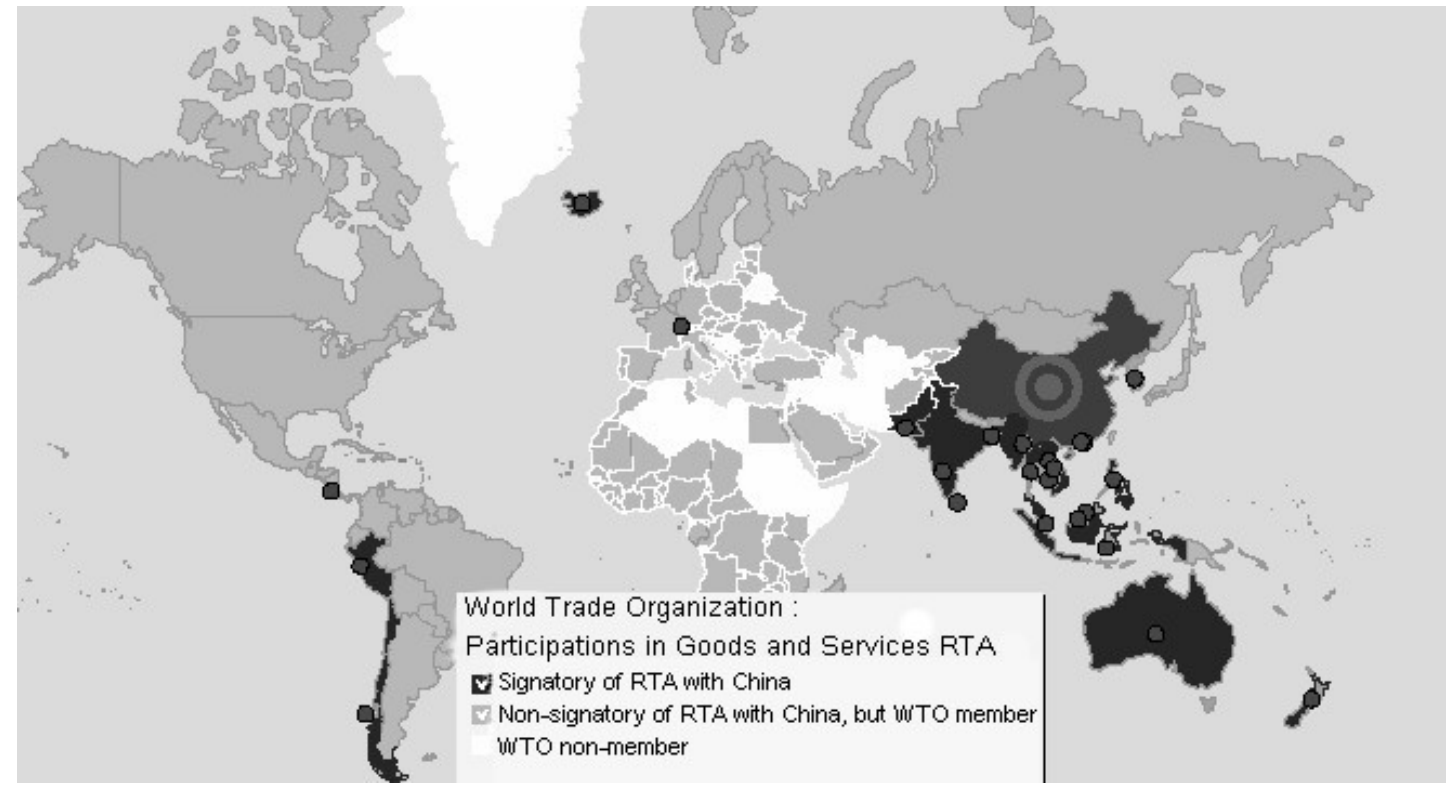

Figure 3. Regional Trade Agreements with China in force (WTO, 2016)

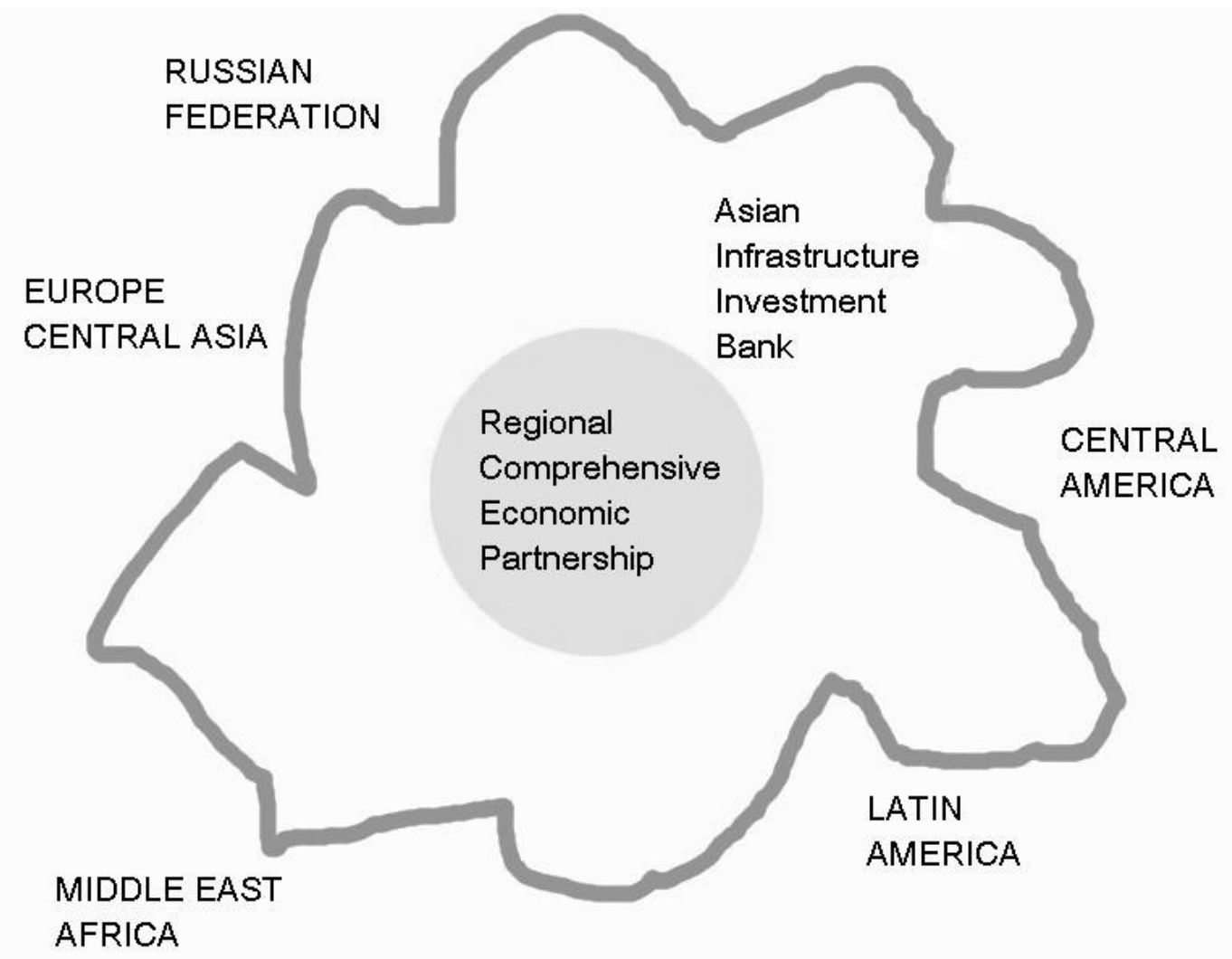

Figure 4. Asian "fried egg" regionalism 
The evaluations of "spaghetti regionalism" indicate that creation of traffic dominates, and that does not normally affect non-signatory countries (Freund, Ornelas, [12]). The "spaghetti dish" of China remained medium in size, even as the volume of trade and from China increased considerably in the period 2001-2008.

A gradual increase in trade restrictions has occurred after 2008. However, facilitation measures and new regional agreements are also negotiated in this context. The post-crisis regionalism of 2008 therefore has no specific designation in the literature. Some countries, such as Russia and India, have a protectionist orientation, but they appear in the policy of Chinese trade agreements - and thus all analysts reject too simplistic view of "simple" post-crisis protectionism, like the one that followed the crisis in 1929. The Chinese trade policy since 2012 is that a bi-scalar regionalism, One Belt One Road, distinguishing a circle of neighboring countries and a set of corridors. It is a regionalism of egg on the flat (fried egg regionalism), built from the initial spaghetti regionalism. Nationalist and protectionist countries are found in the first circle of neighbors (e.g., India), as well as the Corridor policy (e.g. Russia). New partners are introduced both in the Corridors (e.g. Kazakhstan) and in the Belt of Neighbors (e.g. Japan).

Since 2008, Asia Pacific has improved its economic integration, with Japan exceeding the 50\% trade in the zone in 2009. An extension of the production chain to neighboring countries with low wages is also observed and tempering Asia's slowdown in global trade. For China, the winner of the globalization, a regional consolidation provides a new unifying project, allows external support to a development the regions of the West China, and offers opportunities to China's financial and productive capacities (Ferdinand, [10]; $\mathrm{Yu},[27])$.

\begin{tabular}{|c|c|}
\hline RCEP & AIIB \\
\hline $\begin{array}{c}\text { ASEAN : Brunei, } \\
\text { Cambodia, Indonesia, Laos, } \\
\text { Malaysia, Myanmar, the } \\
\text { Philippines, Singapore, } \\
\text { Thailand, Vietnam } \\
\text { + six ASEAN's FTA : } \\
\text { Australia, China, India, } \\
\text { Japan, South Korea, New } \\
\text { Zealand }\end{array}$ & $\begin{array}{c}\text { RCEP without Japan } \\
22 \text { “regional” countries : Azerbaijan, } \\
\text { Bangladesh, Georgia, Iran, Israel, } \\
\text { Jordan, Kazakhstan, Kuwait, } \\
\text { Kyrgyzstan, Maldives, Mongolia, } \\
\text { Nepal, Oman, Pakistan, Qatar, Russia, } \\
\text { Saudi Arabia, Sri Lanka, Tajikistan, } \\
\text { Turkey, united Arabs Emirates, } \\
\text { Uzbekistan } \\
20 \text { "non-regional” countries (Brazil, } \\
\text { Europe, Africa) : Austria, Brazil, } \\
\text { Denmark, Egypt, Finland, France, } \\
\text { Germany, Iceland, Italy, Luxembourg, } \\
\text { Malta, Netherlands, Norway, Poland, } \\
\text { Portugal, South Africa, Spain, Sweden, } \\
\text { Switzerland, United Kingdom }\end{array}$ \\
\hline $\begin{array}{l}16 \text { countries; } 30 \% \text { of World } \\
\text { GDP; } 3,4 \text { billion people }\end{array}$ & 57 countries \\
\hline
\end{tabular}

Figure 5. RCEP \& AIIB

Until 2016, US trade policy highlighted the Trans Pacific Partnership (TPP) - with Japan, but without India and China and the Transatlantic Trade and Investment Partnership
(TTIP) with European Union. Japan is participating in the RCEP negotiations unify ASEAN RTAs, but has established an independent Development Bank. In a Hub and Spoke scheme, where hubs would be the major areas of innovation, and spokes the major trade flows connecting the three main hubs, North America, Asia and Europe, the affirmation of a new regionalism tends to slip "Spokes" (orientation of the agreements TPP and TTIP) towards the Hubs, through a refocusing towards their intra-regional exchanges. A periodization following "spaghetti regionalism" in which trade agreements accompany large volumes of intercontinental flows, an "egg-on-the-plate" regionalism, which the trading partners of each Hub seek to strengthen their ties in a "hard core" would be confirmed.

The theoretical instruments to analyze this "new regionalism" remain largely to develop, literature being focused on the effects of proximity, while the new regionalism articulates on major trade roads of $10000 \mathrm{~km}$ long and do it involve "remote effects" that have no theoretical status (see [21] for theoretical evolution).

We will progress as follows: first, specify an intense trade flows approach (\$2). We then discuss the case of the Silk Road yesterday ( $(3)$ and today $(\S 4)$.

\section{Define an Approach of «Intensive Exchanges Flows»}

Globalization is a transformation of macroeconomics solidarities. Before 1986, proximity effects are very important; neighbors solidarities facing exogenous shocks (oil crisis ...). Since 1986, global business cycle is based on a more or less highly dynamic of exchanges.

The trade positively affects the transmission of knowledge. Being in the Grossman-Helpman literature vein (from [3]), a recent study indicates that this relationship is nonlinear (Fracasso \& Vittucci, [11]): the trade affects, in such a nonlinearly way, the transmission of knowledge. That is to distinguish three groups of countries. A first group of countries contributes only weakly to international trade in goods and has no impact on growth or knowledge. Intermediate countries are in a gradual emergence of benefits. Finally intense trade flows, however, quite low above average flows (a threshold about $114 \%$ according to the cited study, [11]), multiply the benefits.

In the ranking of countries by their dynamism for innovation, the first major country that is not affected by the new regionalism OBOR / TPP / TTIP is Argentina. The country is in the $72^{\text {nd }}$ place (out of 141 listed in 2015: Dutta, Lanvin \& Wunsch-Vinc)]]]ent, [9]). The New Regionalism concerns all countries with strong trade flows and a high level of innovation, as well as countries in Central and South Asia crossed by these flows. The fast progress of China in the same ranking illustrates undoubtedly this nonlinearity proposed by recent studies ([11]; Guy, [14]). The Silk Road has gone from an indolent regime to a fast regime, having a 
ripple effect for the high-tech content of traded goods.

In Romer vein literature, innovations are new combinations and growth results from the variety of goods and services. From a Model of three Sectors (R\&D, good capital and final good), two countries, it can be characterized two growth regimes': either $G_{\text {inf }}$, indolent growth, or $G^{\text {sup }}$ the optimal growth (Darreau, [5]). $\mathrm{G}_{\text {inf }}$ is obtained in autarky, or freedom of capital or equipment but not of knowledge. $G^{\text {sup }}$ is obtained with freedom of final goods and free diffusion of knowledge combined. If there is freedom for knowledge, but not for capital or equipment, $G^{\text {sup }}$ is still obtained (Darreau, [5]). Here, the approach of Romer emphasizes the variety of goods and services: there may be two groups of countries, one with few primary products (energy, agricultural products), the other group exchanging a wide variety of products and services.

Literature «C-A-G-E-T-» on the effects of distance was submitted by Ghemawat ([13]): Whether a distance (or conversely, proximity) Cultural, Administrative, Geographic, Economic and Technological plays. For example : in alliances for R\&D between firms, technology proximity and especially short Geographic distance plays more for R\&D then for trade agreements; the administrative distance is more sought after than legal security is acquired. Cultural proximity and cultural distance does not play (Choi \& Yeniyurt, [4]). For alliances in the European biotechnology sector, firms prefer the proximity for technology and the legal protection of rights, but they prefer diversity and distance for administrative, commercial and cultural factors (Angué \& Mayrhofer,[2]). In total, the CAGET literature indicates greater distancing for commercial activities than for R\&D, and a mix strategy Proximity / Distance contradicting the theoretical approaches which are based either proximity, either universality of knowledge center and full dematerialization of economic relations. His can be designed according to the sequence of development of the innovation. In accordance with the approaches "CAGET" neither a pure universal operator nor pure proximity operators seem desirable. For example, universities need being on the technological frontier, and realize dissemination work towards more peripheral entities. Universities may be regarded as operators of distancing.

Remote effects were characterized empirically, for example in the literature CAGET. It can be advanced theoretical explanations in each of the remote effects recorded.

The pure strategies of proximity or distance seem unrealistic for a complete innovation process. At the beginning of this process, a more favorable to the nearby mixed strategy seems more likely, while marketing phases seem more favorable to mixed strategies using more the distance.
The comparison with empirical data suggests a most active reason for prevention in regionalism after 2008 crisis. Approaches by variety and proximity or distancing effects have an explanatory power for spatial differences. Finally, the joint effects of knowledge and intensification exchanges make it possible to explain the regionalism associated with globalization. Spatial coherence differentiates an "egg on plate" regionalism from "spaghetti" regionalism.

\begin{tabular}{|c|c|}
\hline Acronym CAGET & Explanations of remote effect \\
\hline C for Culture & Prospecting Reason \\
\hline A for Administrative & Regulatory opportunity reason \\
\hline G for Geographic & Truth : "no one is a prophet in his village" \\
\hline E for Economic & Diversification, speculation \\
\hline T for Technology & $\begin{array}{c}\text { Technological complementarity, technology } \\
\text { watch }\end{array}$ \\
\hline
\end{tabular}

Figure 6. Remote effects

\section{Exchanges and Knowledge: The Silk Roads}

When Marco Polo dictated the "Divestment of the World" in 1298 ([22]) in Genoa prison, he embodies all remote effects. It was seen as a storyteller in Venice - «no one is a prophet in his village» -, after having done a career in Chinese imperial administration as envoy of the emperor. The Venetians arrived in China for the commercial speculation pattern, and they integrated as an inspector in direct service of the imperial house. The reasons of regulatory exploration and technological watch are those of the private intelligence officers of the imperial court under the Mongol dynasty. Thus, the effects of distance even pre-exist when the volumes and variety of exchanges are very low.

Schematically, the Silk Road knew several reversals of their main axis of distribution, and their scheme for remote effects. Needham had advanced a general advance in the state of science and technology in China for very long time. The work of Maddison came modulate this assertion, by providing support elements to Chinese texts indicating the existence of a great political and economic empire in the far west of Eurasia (presumably, the Roman Empire). In one first inflexion point spotted by Needham, China's decline with dynasties Ming (1368-1644) and Qing (1644-1911), adds an original transfer of innovative trends around the middle of first millennium our era (AD), with the clearing of the western European and affirmation of the Chinese empire and the Silk Road (Soutif, [25]). 

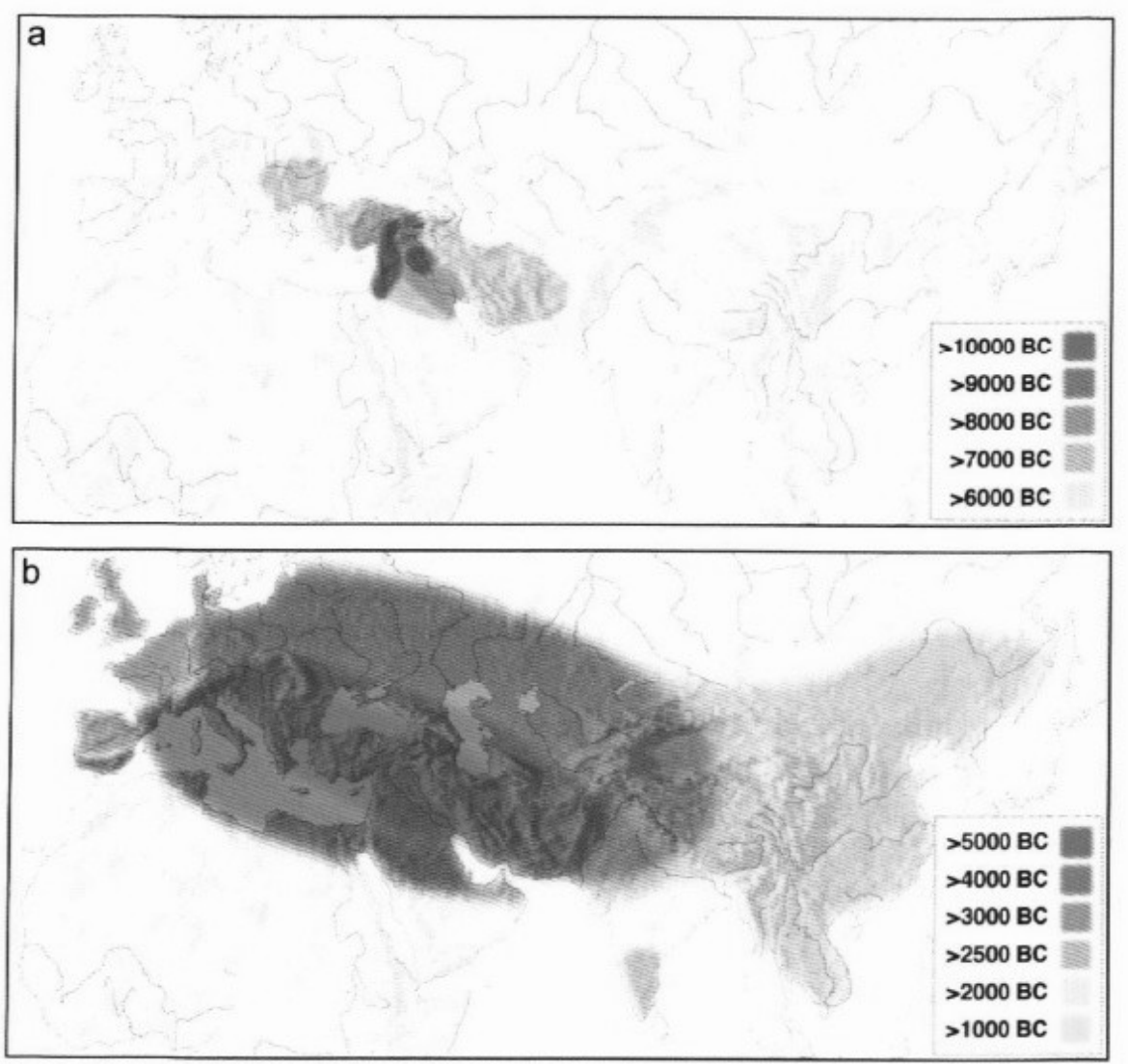

Figure 7. Silk Road : Broadcasting axis of the productive economy

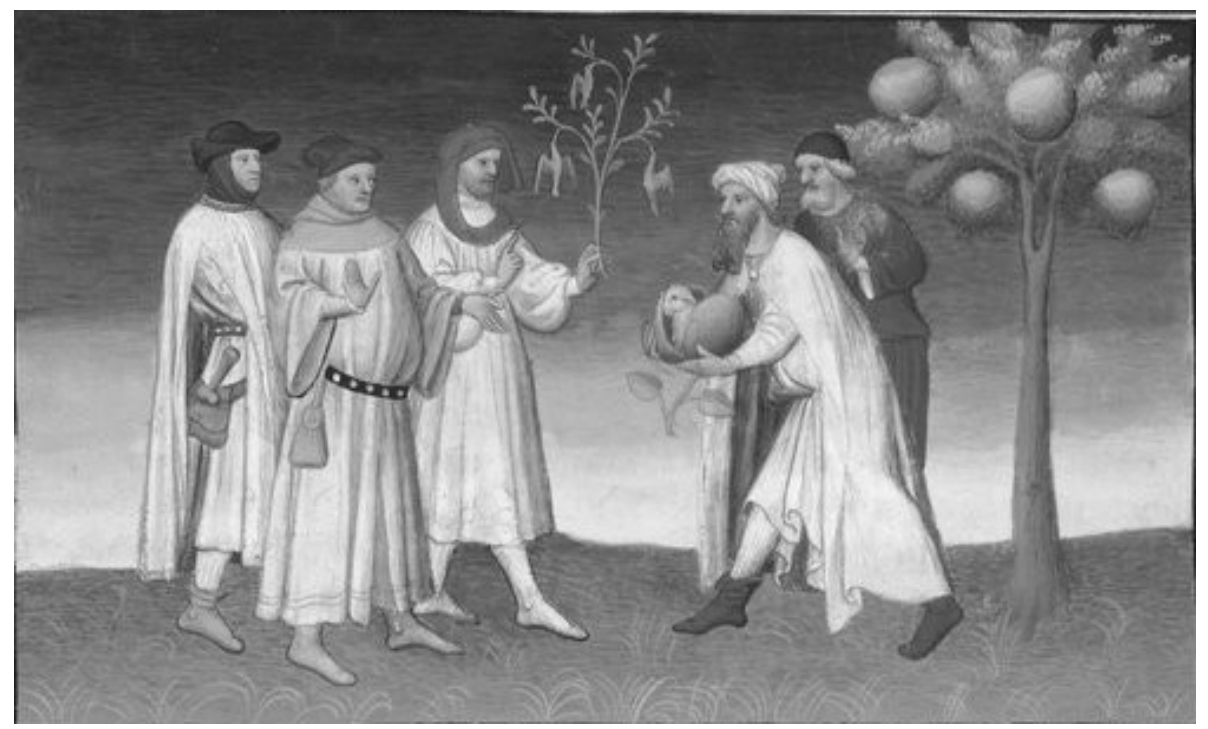

Figure 10. Wonders exchanges between Western and Eastern merchants (folio 210 of the manuscript of the National Library in Paris) 


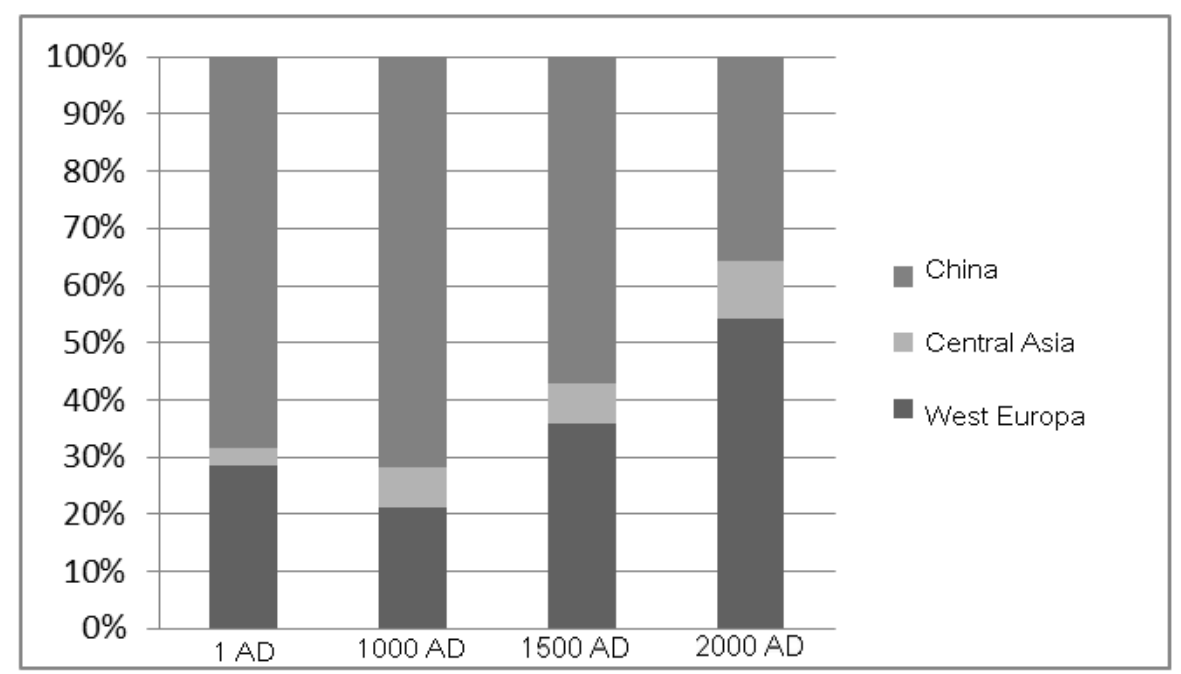

Figure 11. From year 1 to 2000 , distribution of wealth on the Silk Road

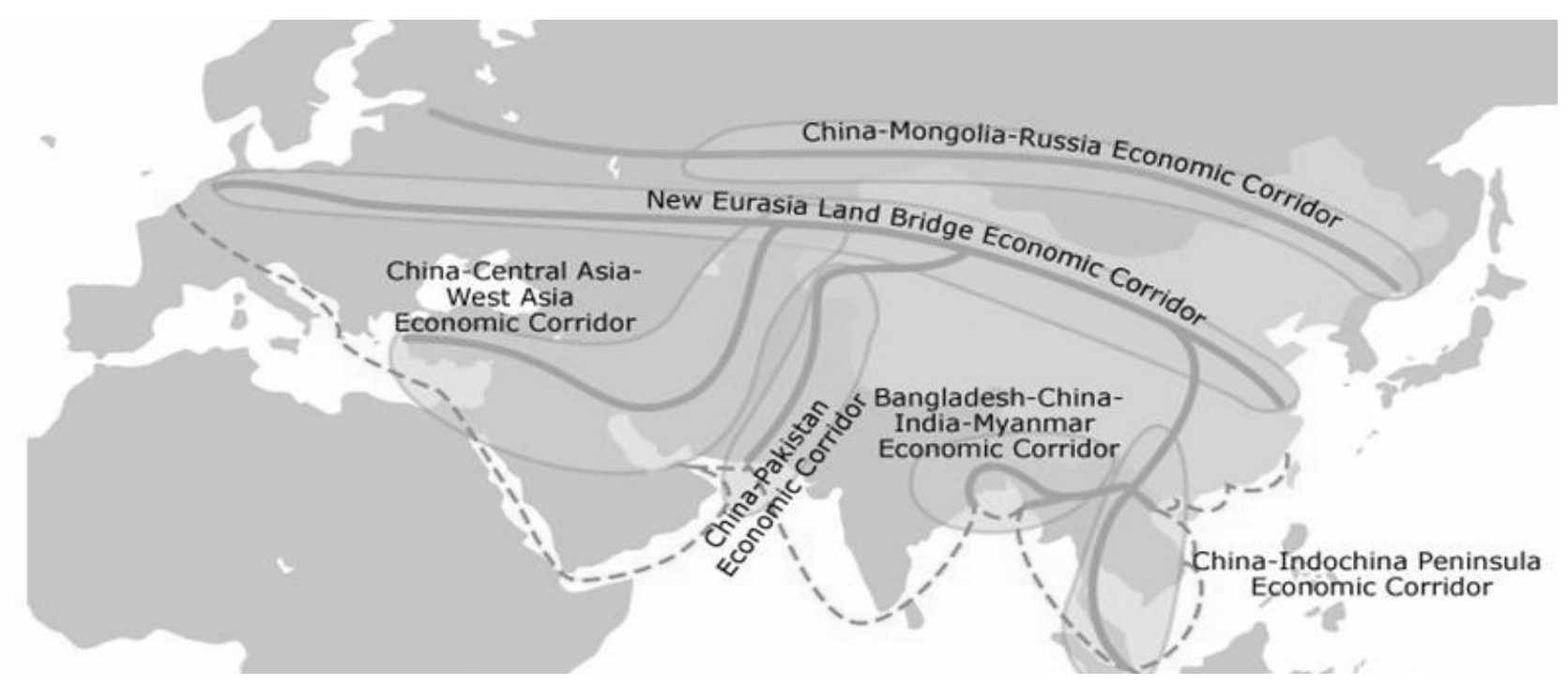

\begin{tabular}{|c|c|}
\hline New Eurasian Land Bridge & $\begin{array}{l}\text { Objective: reduce the transportation time by a direct route } \\
\text { Means: connecting European and Chinese networks in the territory of Kazahstan }\end{array}$ \\
\hline China-Mongolia-Russia Corridor & $\begin{array}{l}\text { Objective: Improvement of the Transsiberian routes } \\
\text { Means : investing in Mongolia infrastructure }\end{array}$ \\
\hline China Central Asia/West Asia Corridor & $\begin{array}{l}\text { Objective: to ensure China's energy supply } \\
\text { Means : connecting gas pipeline networks and oil pipelines from Central Asia; investments in Turkey, } \\
\text { Iran, Kyrgyz Republic, Tajikistan, Kazahstan }\end{array}$ \\
\hline China-Indochina Peninsula Corridor & $\begin{array}{l}\text { Objective: to develop land links between Singapore and Hong Kong } \\
\text { Means : TGV and motorway connections in Cambodia, Laos, Myanmar, Thailand }\end{array}$ \\
\hline China-Pakistan Corridor (« blood road ») & $\begin{array}{c}\text { Objective: to develop a land / sea mixed track via the port of Gwadar Means: infrastructure } \\
\text { development in Pakistan } \\
\text { Difficulties: problems of Kashmir, disputed region between India and Pakistan, and high mountain } \\
\text { routes (pass at } 4,700 \mathrm{~m} \text { ) }\end{array}$ \\
\hline Maritime road (« spices road ») & $\begin{array}{l}\text { Objective: improve cabotage and secondary maritime roads } \\
\text { Means : improving the intermediate port infrastructure }\end{array}$ \\
\hline
\end{tabular}

Figure 12. The six corridors of $O B O R$ 


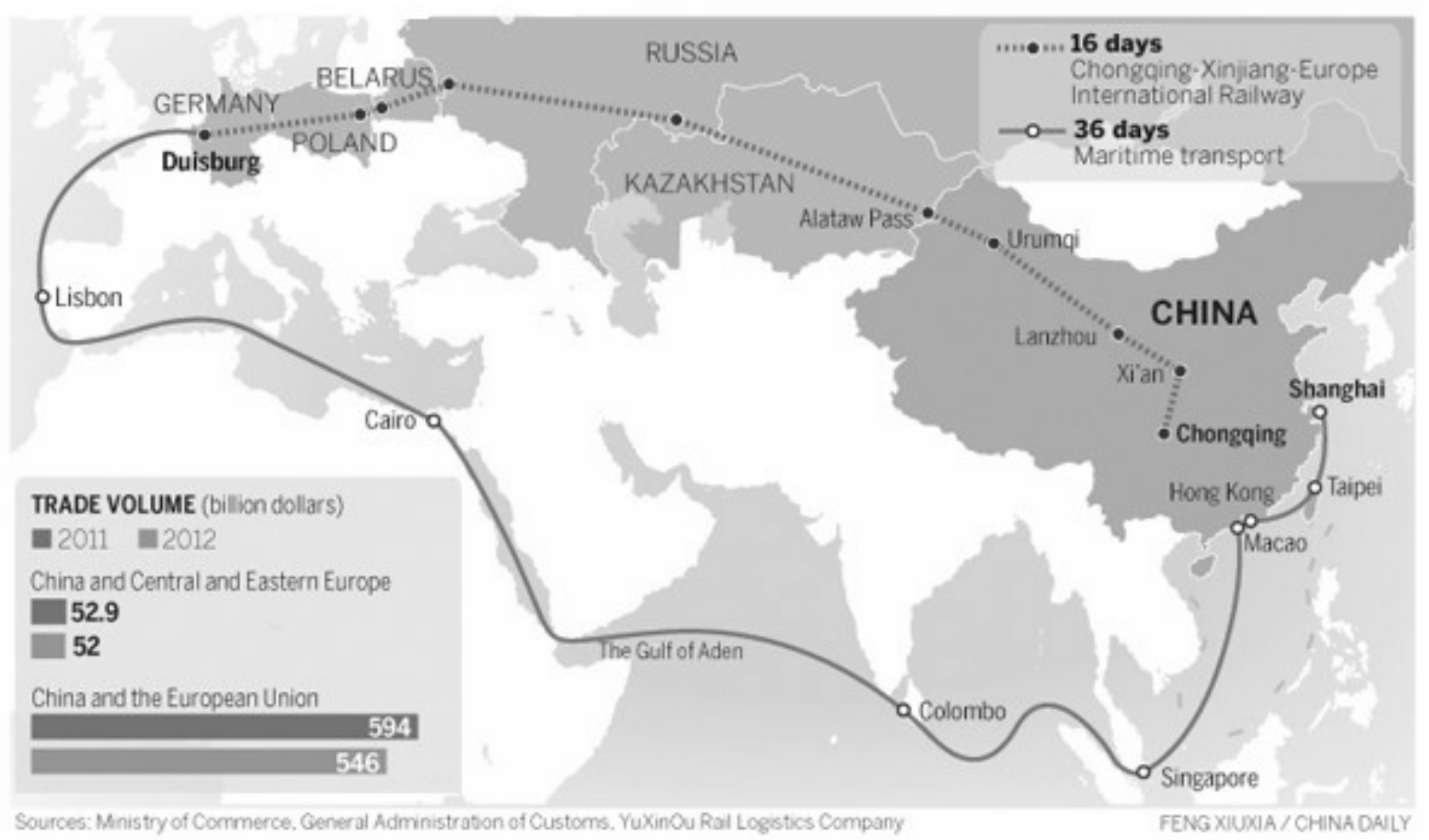

Figure 13. Faster road for trade

The silk will be under that Secret regime until about 500 AD. The emergence of competing Chinese silk productions specializes in luxury. The new regime for knowledge and exchanges was the Wonders. In ancient Roman times, the wonder is defined as for understanding the natural orderprivileged access to an ultimate knowledge. The exchanges Wonders are a regime of trade and knowledge, famous through the manuscripts travels of Marco Polo (write in 1298 $\mathrm{AD},[22])$.

The tribes along the Silk Road are often sold. Wonders exchanges in the diet are limited quantity and quality (some silks are reserved for the imperial court). It is about exchanges which address a clientele restricted by connoisseurs. Restrictions on the amounts remain in use in the Ming and Qing eras. In Europe, the wonders would be operating between 1150 and 1750 (Daston, Park, [6]).

The Silk Road never occurred by a shape of political organization mastering all the roads. An informal regionalism based on large sparsely populated areas is granting freedom of movement has probably existed throughout northern nations of a threat more or less important. Previous analysis (Abba Gana, Callens, Gnassou, [1]) indicates the attraction for sparsely populated areas political diagram juxtaposition of a small mining states, inadequate training the wealth « intense currents of exchanges » factors and political destabilization.

The chaining of three zone pivots (North America, the Northern Europe, East Asia) by intensive currents of exchange form the «system-world» of the Trade and the
Innovation of today. Spillovers do not correspond to it in recognizable governances and a promotion of the common growth only very imperfectly existing international institutions, as for example the G20 limited competence.

\section{Analysis OBOR}

Trade policy OBOR (一带一路; pinyin: Yídài yílù, New Silk Road) was officially launched by the Chinese Government in October 2013, particularly with a speech by Xi Jinping while traveling in Indonesia. The main institution of multilateral OBOR is the AIIB. China has $26 \%$ of the voting rights in the AIIB. The capital of 100 billion $\$$ comes from $75 \%$ of Asian capital. Another bank of OBOR, the Silk Road Fund, is fully Chinese-funded at the level of 40 Billion $\$$.

The new Silk Road, which involves six corridors, 5 terrestrials and 1 marine, is to reduce non-tariff costs of new transport infrastructures (rail, road, pipeline and gas pipelines). For example, rail link Karakorum ("blood" road through the Himalayas) between China and the Indus Valley is scheduled. "Belt" countries are the most affected: Mongolia, Kazakhstan and Pakistan.

The OBOR program has an inner dimension for China. The spatial distribution of wealth and knowledge is spatially very inegalitarian with a strong concentration in the coastal zone. Similarly, maritime corridor captures $99 \%$ of material flows, while only a few trains make the direct connection 
between China and Duisburg each week

The opening of rail links between China and Europe is the part of the OBOR program that has been evaluated $(\mathrm{Li}$, Bolton, Westphal, [18]). This is indeed a creation of traffic, with the European export of perishable products which could not be before. The rail freight of the New Silk Road brings a drop in the cost of transport, which intensifies the flows.

The general conception of OBOR is that of an entry in a multipolar world. Regional approach to non-tariff reduction, in addition to a multilateral approach to tariff costs. There is a willingness to search by regional cooperation with neighboring countries. The cooperation with countries without natural resources is displayed (Ze, [28]), which implies an encouraging innovation component. The approach is centralized, inscribed in a policy of the Chinese one-party. The reference to a "Marshall Plan" that was put forward by commentators is explicitly rejected by the promoters of the OBOR. Commentators are based on common features in OBOR and Marshall Plan: not targeted on the reduction on tariffs and kind with bilateral intergovernmental aspects. Unlike points are the "containment" of a threat to the defense of a cold war border was the Marshall Plan, and the gift of consideration that was appearance with that of the Marshall Plan, China advocating noninterference.

\section{Conclusions}

Pascal Lamy have compared both the TPP negotiations and TTIP, indicating that one reflects a decrease of concern protectionism (TPP agreement), and the other (trading TTIP) tries to harmonize precautionary administrations (Lamy, [15]). The initiative of the Chinese OBOR reintroduces a development issue. The Agreement on Trade Facilitation was signed in Bali in December 2013, and harmonization of customs procedures within the framework of the Doha Round has been delayed by the veto of India. The New Regionalism has been accelerated by this setback addresses additional questions.

Since 1990, the literature on innovation remained in line with the districts. The benefits were seen having a single span, measured at 50 miles (Döring, Schnellenbach, [8]). Arithmetic in the resulting policy was simple, with a complete network by a set of universities, each university corresponding to an area of approximately $20,000 \mathrm{~km}^{2}$. OBOR a type of policy is dual significance: One Belt of politics is an enlargement policy focused on research and innovation, the policy of One Road is longer range, aimed at facilitating trade and developing corridors.

The delay by India in the development of maritime routes is assigned to another type of multi-scalar policy (Nekrouf, [23]). Indian ports are saturated in a complex system of governance bicephalous (Region and Federation) and the double structure (regulated Ports Major and Minor), having lost the ability to appropriate investment policy.
Innovation policies would be carried by "biscalars" organizations operating simultaneously at two scales, an average scale for upstream $R \& D$, and a large scale for the downstream market access - that suggests this Asian comparison.

In the long term, it is the regimes of knowledge that transform the roads of silk. Globalization has introduced regionalization based on the joint effects of knowledge and trade. The 2008 crisis strengthened economic ties in the Asia-Pacific region. On the contrary, Central Asia is marked by instabilities and compartments. The Chinese initiative OBOR must meet these challenges and opportunities for Asian regionalism.

\section{REFERENCES}

[1] Abba Gana S., Callens S. \& Gnassou J. (2014) Le Régionalisme informel, Les cahiers de l'ATM, 29, 27-36.

[2] Angué, K., \& Mayrhofer, U. (2010). Coopérations internationales en R\&D: les effets de la distance sur le choix du pays des partenaires.M@n@gement, 13(1),2-37.

[3] Coe D.T., \& Helpman E. (1995). International R\&D spillovers, European Economic Review, 39, 859-887.

[4] Choi, J., \& Yeniyurt, S. (2015). Contingency distance factors and international $\mathrm{R} \& \mathrm{D}$, marketing, and manufacturing alliance formations. International Business Review, http://dx.doi.org/10.1016/ j.ibusrev.2015.04.007

[5] Darreau, P. (2003), Croissance et politique économique, Bruxelles : De Boeck.

[6] Daston L., Park K. (1998), Wonders and the Order of Nature 1150-1750, New York: Zone Books.

[7] Deng G. (1997). Chinese maritime activities and socioeconomic development 360 BC 1900 AD, Westport: Greenwood.

[8] Döring T., \& Schnellenbach J., (2004, January). What Do We Know About Geographical Knowledge Spillovers and Regional Growth? A Survey of the Literature, Research notes working paper series, No. 14, Deutsch Bank Research.

[9] Dutta S., Lanvin B. \& Wunsch-Vincent S. (2015) (eds.) The Global Innovation Index 2015, Geneva: World Intellectual Property Organization.

[10] Ferdinand, P. (2016). Westward ho - the China dream and "One Belt, One Road": Chinese foreign policy under Xi Jinping, International Affairs, 92, 4, 941-957.

[11] Fracasso, A. \& Vittucci Marzetti G. (2015, May) International Trade and R\&D spillovers, Journal of International Economics. May 2015 96(1):138-149 DOI: 10.1016/j.jinteco.2015.01.010

[12] Freund C., Ornelas E. (2010), Regional Trade Agreements, Annual Review of Economics, 2, 1, 139-167.

[13] Ghemawat P. (2001 September). Distance still matters. The hard reality of global expansion, Harvard Business Review, $79,8,137-147$. 
[14] Gozagnadou D. (2013), La Poste à relais en Eurasie (2e éd.), Paris: Kimé.

[15] Guy D. (2011), Des pas de géant dans la R\&D: de l'usine du monde au laboratoire du monde, Revue internationale et stratégique, 1, 81, 133-138. DOI 10.3917/ris.081.0133

[16] Lamy P. (2015). Le nouveau monde du commerce, Commentaire, 151, 491-498.

[17] Laruelle M., Peyrouse S. (2010). L'Asie Centrale à l'aune de la mondialisation: Une approche géoéconomique, Paris: Armand Colin.

[18] Li Y., Bolton K., Westphal T. (2016). The effects of the New Silk road Railways on Aggregate Trade volumes between China and Europe, Working paper 108, Institute of East Asian Studies, University of Duisburg-

[19] Messini Petruzzelli A. (2011). The impact of technological relatedness priorities, and geographical distance on university-industry collaborations: a joint-patent analysis, Technovation, 31, 7, 309-319.

[20] Morita K., Chen Y. (2010). Transition, Regional Development and Globalization: China and Central Europe, Denvers:

[21] Moulaert F., Mehmood A., (2008). Analysing regional development: from territorial innovation to path dependent geography, Géographie, économie, Société, 10, 199-222.
[22] (Polo Marco) Livre des merveilles du monde, ms fr. 2810, Bibliothèque Nationale, Paris (ill. Boucicaut workshop, circa 1412)

[23] Nekrouf S. (2014). La gouvernance biscalaire des ports en Inde face aux défis de la mondialisation, Géotransports, 4, 55-70.

http://www.cnfg.fr/Transport/images/stories/Revue/n04/pp55 -70-Gouvernance-des-ports.pdf

[24] Rolland N. (2015). La Nouvelle Route de la Soie. Les ambitions chinoises en Eurasie, Politique étrangère, 3, 2. Doi: $10.3917 /$ pe. 153.0135

[25] Soutif M. (1995), L'Asie, source de sciences et de techniques, Grenoble: PUG.

[26] Yu H. (2016). Motivations behind China's « One Belt, One Road " Initiatives and Establishment of the Asian Infrastructure Bank, Journal of Contemporary China, doi : 10.1080/10670564.2016.1245894

[27] Yu N., De Jong M., Storm S. \& Mi J. (2013). Spatial spillover effects of transport infrastructure: evidence from Chinese regions, Jo. of Transport Geography, 28, 51-66.

[28] Ze S. (2014). Discours de présentation de l'OBOR à l'Institut Schiller,http://newparadigm.schillerinstitute.com/fr/media/on e-road-and-one-belt-and-new-thinking-with-regard-to-conce pts-and-practice/ 